\section{English as Medium of Instruction Implementation for Communication and Sustainability in 4.0 Era}

\author{
1 Shiyrah Theosebes Sela \\ 2 Joice Yulinda Luke
}

12 Universitas Bina Nusantara, Jakarta, Indonesia

\begin{abstract}
Globalization spreads fast around the world put English language become a-must-have skill. Almost all people use English in the teaching learning process, communication, transferring soft skills and hard skills, showing social status in communities, business transactions, political purposes, even on the some medicine instruction, food ingredients, mechanic usage instruction, and many more. The language is used to various purposes, as for online and offline communication. During this corona virus pandemic, English as a Medium of Instruction is implemented mostly in online educational institutions. English as Medium of Instruction is also applied to any subjects in universities in nonEnglish speaking countries. This research focuses on the implementation of English as Medium of Instruction for communication and sustainability in 4.0 era for non-English lecturers in a private university in Indonesia. The survey questionnaires used online link was randomly sent to 53 lecturers as informants. The aim of using online link to support data gathering is to ensure all information required can be collected on time, faster and efficiently. The data was quantitatively presented and qualitatively analyzed. The data collected were information on how essential English related to English of Medium of Instruction implementation for communication \& sustainability in 4.0 era, including the challenges faced by non-English lecturers in fully English as Medium of Instruction classrooms. The findings of this research provide updated information regarding the learning needs and the effective teaching-learning method in implementing EMI for communication and sustainability in 4.0 era.
\end{abstract}

\section{Keywords}

EMI

Communication \& Sustainability 4.0 Era

\section{Ethical Lingua}

Vol. 7, No. 2, 2020

ISSN 2355-3448 (Print)

ISSN 2540-9190 (Online)

Corresponding Email

Shiyrah Theosebes Sela

ssela@binus.edu

Article's History

Submitted 23 Sept. 2020

Revised 7 October 2020

Accepted 9 October 2020

DOI

10.30605/25409190.219

Copyright $\odot 2020$

The Author(s)

This article is licensed under CC BY-NC-SA 4.0 License 


\section{English as Medium of Instruction Implementation for Communication and Sustainability in 4.0 Era}

Nowadays, the fourth industrial revolution known as 4.0 era, the innovative and qualitative nature takes control. In the era of industrial digitalization, organization or companies are allowing their routines to be integrated for data collection and analysis and evaluation for performance improvement (Nagy, Oláh, Erdei, Máté, \& Popp, 2018). Data holds the main roles as all around the world require data or information to continue their activities, run their plan and reach their goals. Government of a country, and even the worldwide started to produce the strategic initiative to deal with industry 4.0. The purposes of the initiative are transformation of industrial to digitalization and the usage of information, communication, and technology. The production shifts to system that is flexible so it will be individualized and customized. Education in 4.0 era focuses on the innovation and the usage of Internet, information, and technology. This is also applied to some subjects, added Rojko (2017) and Baena, et al. (2017). The Internet, information and technology take control of all activities inside and outside the education field. Now, almost every field of people life runs with the support of Internet, information and technology. It is known that the pandemic of Corona virus put most people around the world inside their houses, places and run all the activities from there. All the activities here are businesses, managements, shops, studies, courses, survey, researches, and many more. This situation urges people to use and benefit the Internet, information and technology.

In the era 4.0, world has changed, and to keep up the pace, future development plan has to be managed to support the lecturers in teaching - learning (Vuksanović, Ugarak, \& Korčok, 2016). The era of 4.0, where the artificial intelligence and digital physical frameworks produce human-machine, Shahroom \& Hussin (2018) wrote that education must adapt with new model of education that focus on improving the skills that could not be replaced by Al or digital physical. As the Al continues grow in getting adjust with human needs, feeling and consideration; so education must keep growing. We could approach the era of 4.0 industrial revolution by creating or planning the application of smart technology concepts (Lalic, Vidosav, Marjanovic, Delic, \& Tasic, 2017). Smart technology concepts are easy to see around us to support human needs in almost every aspects of life. Smart phones, smart television, smart cards, smart car and other smart system which integrated or connected each other are the common things in this era. Santos (2018) argued that it has been accepted that technology related to era of 4.0 would have great impact to industries in the future. Challenges faced by society and education by 4.0 era would be lack of digital culture, training, knowledge, and language. Hariharasudan \& Kot (2018) said that digital English and education 4.0 are the required skills of employees. It becomes one of the requirements to poses a certain minimum skill of English to apply in companies, educational institutions, government offices and other. The lack skills of English language will decrease the opportunity in gaining big deal. Mastering English language will benefit and support the career as well as the education of an individual. Not just English is required but mastering English will support to get wider knowledge and deeper understanding as all the instruction mostly written at least in English. The era of 4.0 is fully automated and smart production as Piccarozzi, Aquilani, \& Gatti (2018) mentioned in their research. The knowledge how to conduct and operate all the stuff are known best written at least in English. So that is why the using of English in transferring knowledge must started 
when people in education institution, from young learners to adult learners. Fact that the development of technology and sciences in era of 4.0, brought significant impact on human life. Digital technology created shift on the education system. English has been an integral part of the technology (Angelianawati, 2018).

We can find many educational institutions introduce the learning experience taught in foreign languages. These types of education have been introduced from pre-school up to any educational groups. There are many educational settings in which 'content' is taught in a language other than the home language of the students (Macaro, Curle, Pun, An, \& Dearden, 2018). Here, in Indonesia most private schools sell the methods of delivering learning content in other language than the mother tongue language. This situation pushed by the paradigm of going international as the main point to do in the future. Kremer \& Valcke (2014) added that the implementation EMI (English as Medium of Instruction) in higher education has become real in some countries. Especially in the countries with English is not the first spoken language, the needs to be stand out or join the internationalization or be a part of the globalized community; the educational institution, academies, universities offer the program that put EMI as the main point to reach. This EMI program is expected to overcome all the challenges that might be faced in the future. As there were still debates on English as an International Language, the implementation of EMI in higher education produced high concern according to Coleman (2006). Until now, English language is still one of the most languages used in the world. Although some countries still consider their own languages as the international languages, but English is proven to be used worldwide. In Indonesia, mastering English language almost we can say considered as one of the tickets to go international, to be part of the worldwide community or to be considered as ready to compete with others.

The importance of English language is beyond the skills attained in formal and informal education institutions. The communication using English language between people are required for era of 4.0. Some workplaces define the skills of communication in English is a must-have competency to sustain in industry 4.0 explained Shuhaimi \& Awaludin (2018). English language has openly used as communication tools in ages. The open communication, safe, secure with the complied standard of platforms required in era of 4.0 as basic communication system according to Zezulka, et al. (2018). Communication required to gain knowledge, to conduct strategic communication. Communication is a process, the sustainability of meaning presentations and negotiations (van Ruler, 2018). Communication required to transfer meaning of verbal and non-verbal signs. People have the needs to express themselves internally and externally as the effective communication to develop sustainability and sustainable strategies (Genç, 2017). Participation of people and development of communication are the important key factors for the sustainable development (Fitryarini, 2018).

Internationalization or a situation to cultivate and develop multilingualism becomes a part of being as the worldwide university, so EMI more becomes unavoidable force in higher education system in many non-English speaking countries (Shimauchi, 2018; Doiz, Lasagabaster, \& Sierra, 2011). During this pandemic, all around the world are easily meet up and collaborate. People mostly use English language to communicate, work, discuss, learn and socialize. This is what people called as internationalization. This internationalization goes into every aspects of human life. Following up the globalization and the English as a Medium of Instruction implementation, the required skills of lecturers had been reviewed and updated, and it increased the number of concerns to accommodate the changes from English as a foreign language to English as a Medium of Instruction (Dafouz \& Camacho-Miñano, 2016; 
Dafouz, 2018; and Brown, 2016) completed in his respective research. To support and facilitate the learners or students to earn all the required skills, knowledge and all other necessary attributes, lecturers must update and upgrade his or hers first. English as a Medium of Instruction becomes a required plan to implement. The shift was rapidly growing among non-English speaking countries (Briggs, Dearden, \& Macaro, 2018; Brown \& lyobe, 2017). There were the needs of internationalization or being a part of the global community pushed people especially in the countries with other languages except English eager to learn, study, experience and master English language to complete themselves to face the challenges in the future. So many discussions, opinions, debates and theories around related to English and internationalization. History hold the important role as English had been spread around the world, to most countries since many years ago. Together grew, policy is required based on the research conducted by Corrigan (2015) to maintain the implementation of the English as a Medium of Instruction.

A private university in Indonesia invests creative classrooms for a learning space or environment provided by the university to combine all the information, communication, and technology with education. To adjust with the situation of pandemic of Covid-19, this formal educational institution even hold all the teaching and learning process online. Basically, the process of teaching and learning in the university has been guaranteed to be conducted effectively and efficiently. In facilitating more the education 4.0, and fulfilling the needs of learners and educators to run or conduct the teaching and learning process, this research focuses on the three big points. We analyzed the situation and came up with the ideas to find the root of the problem in conducting English as a Medium of Instruction due to communication and sustainability in disruptive era as there were no previous study conducted related to the EMI implementation in this area. We were called to focus our research on: (1) How essential English for communication in sustainability in 4.0 era?, (2) How to successfully implement EMI in 4.0 era?, and the last is (3) What might be the challenges faced by lecturers in implementing EMI in their classes?

\section{Method}

In this research, we used two methods in collecting data and analyzing data. Data was calculated using the quantitative method. Then after we got the data quantitatively, we analyzed the data qualitatively.

This research focused on the English as Medium of Instruction implementation. As the implementation here conducted by lecturers or educators, so we chose lecturers of nonEnglish subjects to become the main respondents for this research. We sent the questionnaire to 53 lecturers of a private university in Jakarta, Indonesia.

We also completed the required data to support the research by collecting data from students as learners. We sent the questionnaire to 52 students from the same university as the lecturers or educators to provide the date required.

We used Google Form for the questionnaires to be sent to lecturers and to students. The link of Google Form, we sent through email to lecturers to fill in. For the students, we used the learning management system that supports the teaching learning process in our university to reach the students. We used this type of online form to collect data faster and efficiently. Using this online form will ease the process of gathering data for the researcher and filling in the data for respondents. All we need is the Internet connection and the compatible devices. 
There were 10 questions given to lecturers as educators who conduct the English as a Medium of Instruction. We then also sent 3 questions to students as the learners. In this article, we limited the data collected from only 3 questions to answer the research questions.

We used mix-method in presenting and analyzing data. Quantitative method used to collect how many respondents answered and chose the specific answers. After that, we presented the data in percentages. We analyzed the data qualitatively.

We first conducted questionnaire survey among the lecturers who taught the subjects in English. We used online link to collect data. There were 16 lecturers replied and filled the questionnaire. We asked them 10 questions. They were asked to answer the questions based on their experience in applying EMI in their classes. Some of the questions were what the challenges they might be faced for teaching in English in their global or multicultural classes, and what factor according to them that could lead to successful implementation of English as a Medium of Instruction.

After we found the result, we wanted to have better understanding on the implementation in era 4.0. So, we decided to collect more data based on the learning needs related to English and English as a Medium of Instruction to the learners. We required data related to the learners in era 4.0. So, for this reason, we conducted the second questionnaire survey. We collected data through online link and sent it to students as learners. There were 52 respondents. They were asked to answer 3 questions related to era 4.0 such as how essential English as a Medium of Instruction in teaching-learning process in university classes, and how important the skills required by leaders in companies or organizations, and the last was, how effective the online teaching-learning method in improving English language skills.

\section{Results}

Findings as the result of the research, we divided into 3 parts. First, the importance of English in EMI implementation in higher education, second is the challenges faced by lecturers in implementing EMI, and the last is the lead factor to implement EMI successfully.

\section{The Importance of English for Communication and Sustainability}

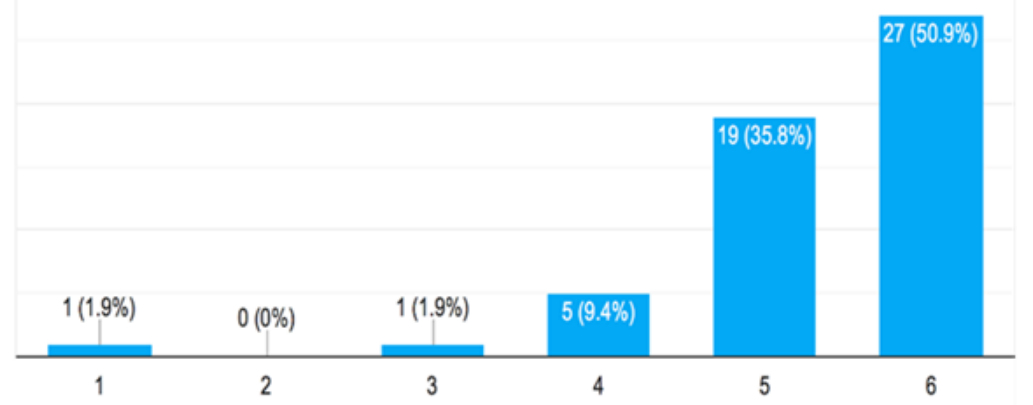

Figure 1. The Importance of English for Communication and Sustainability

Figure 1 above used scale 1 to 6 to show the importance of English, where number 1 is "Very Unimportant", 2 is "Unimportant", 3 is "Slightly Unimportant", 4 is "Slightly Important", 5 is "Important", and 6 is "Very Important". This is the result from question "How essential English as English as a Medium of Instruction in university class in 4.0 era?". Based on the figure 1, we found that $50.9 \%$ respondents thought that English in English as a Medium of Instruction 
was very important, 35.8\% respondents thought that English as EMI was important, 9.4\% respondents thought that English as EMI was slightly important, 1.9\% respondents chose English as EMI was slightly unimportant, and same amount of respondents chose English as EMI was very unimportant. Thus, the result shows that using English as a Medium of Instruction (EMI) in the classrooms for university students is necessary.

English as a Medium of Instruction applied to transfer or deliver many subjects other than English itself. Lecturers who implemented EMI in classes, have shared their thoughts about challenges they faced in implementing EMI. English in this case is considered as language used for communication in 4.0 era.

\section{Challenges faced by Non-Lecturers Lecturers}
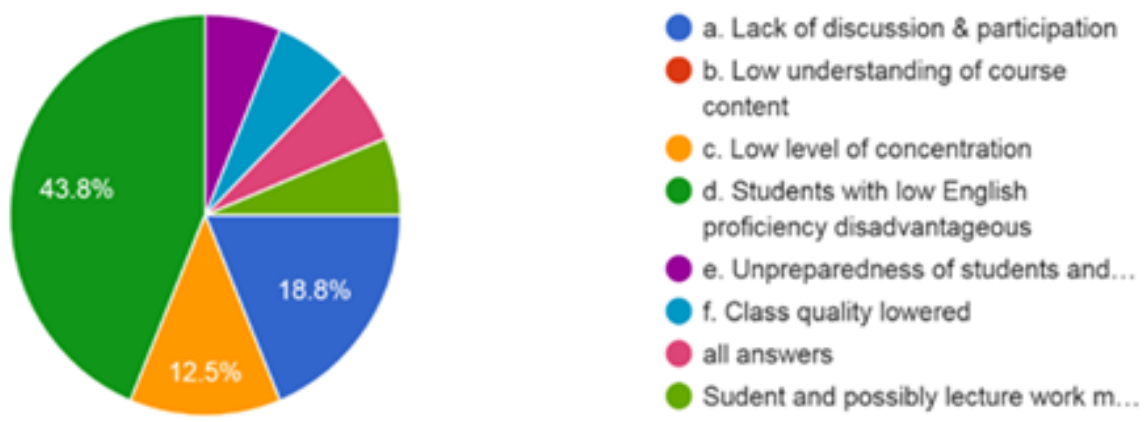

Figure 2. Challenges faced by Non-Lecturers Lecturers

Figure 2 showed that there were some challenges faced by non-English lecturers in implementing English as EMI. This is the result from question "What are the challenges faced by Non-English in implementing English as EMI". This question was given to lecturers. Based on the figure 2, we found that $43.8 \%$ respondents chose the challenges was the students with low English proficiency, and $18.8 \%$ chose lack of discussion and participation, while $12.5 \%$ respondents chose low level of concentration. This result shows that most challenging part in implementing EMI faced by the non-English lecturers was the students with low English proficiency.

\section{Factors to Successful Implementation of EMI}

There were some factors lead to successful implementation of English as a Medium of Instruction. Based on the figure 3, we found that $25 \%$ respondents thought that EMI implementation will be successful if there is an awareness of EMI use, and $25 \%$ thought there should be adjustment teaching speed considering students' English proficiency level, 18.8\% respondents thought the successful implementation of EMI depended on the English proficiency level of students, $12.5 \%$ respondents thought it depended on the lecturers' English proficiency level. Hence, these findings prove that most of respondents chose that to have a successfully implementation of EMI, both lecturers and learner must have the awareness of EMI use. So, there will be no other language used than English for communication. Also, the adjustment of teaching speed considering the students' English proficiency level took part as the important factor. 


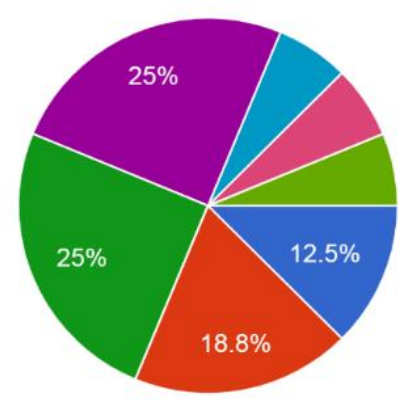

a. English proficiency of lecturer

b. English proficiency of students

c. Sufficient learning materials

d. Adjustment teaching speed

considering student English proficie.

e. Awareness of English Medium Instruction (EMI) use

all answers

All of the above

all of the above factors lead the suc...

Figure 3. Challenges faced by Non-Lecturers Lecturers

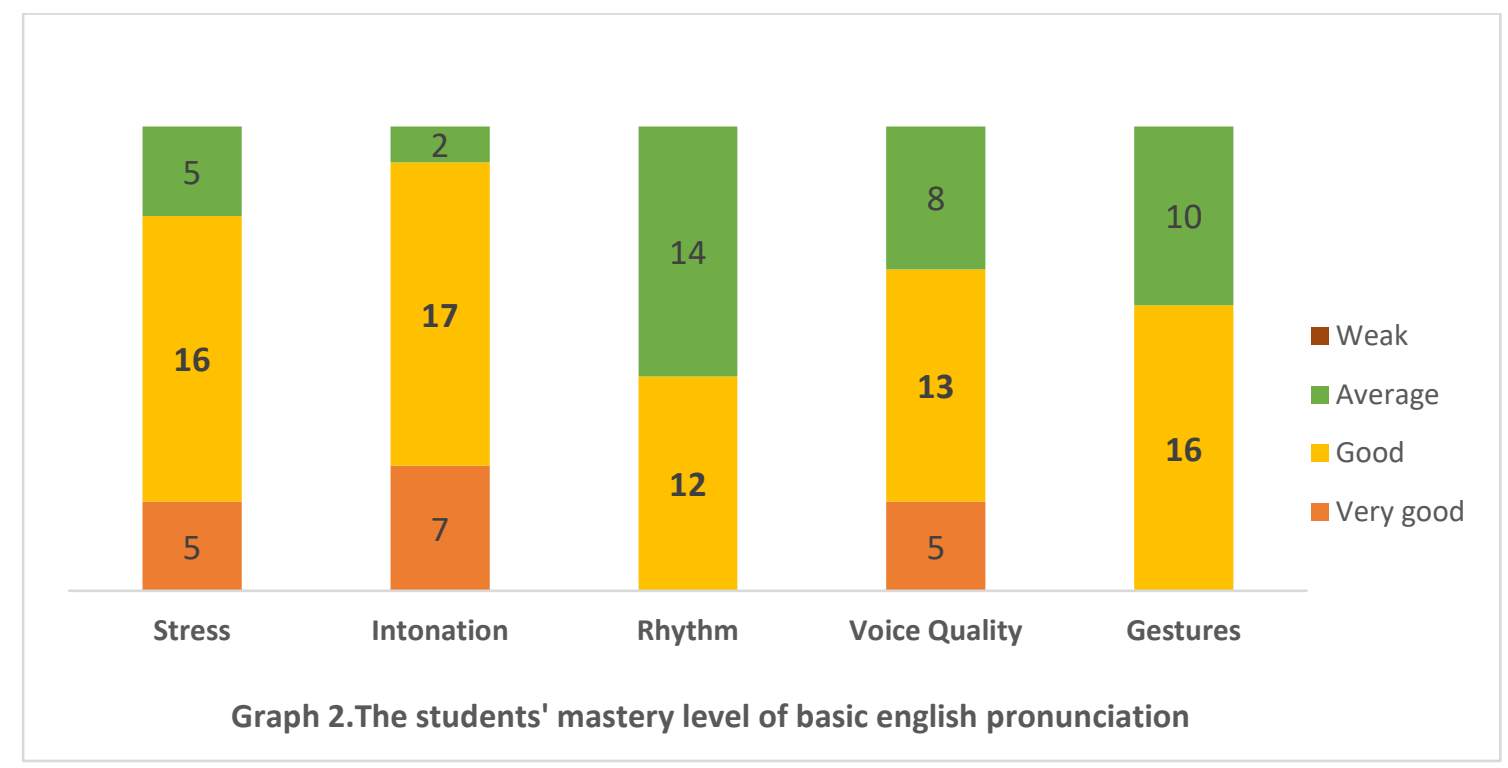

\section{Discussion}

English as a Medium of Instruction applied to transfer or deliver many subjects other than English itself. This situation has been mentioned in research conducted by Rojko in 2017. Lecturers who implemented English as a Medium of Instruction in classes, have shared their thoughts about challenges they faced in implementing EMI. English in this case is considered as language used for communication in 4.0 era (Shuhaimi \& Awaludin, 2018).

Most of the respondents which are lecturers thought that the challenges are the students with low level of English proficiency. These students would hardly understand the content of subjects delivered or transferred. As this found to be one of the challenges, it would be useful for the lectures if they can have students with supported level of English proficiency in their classes. The students require specific level of English to have sustainable learning process. The lecturers will not require to use other language to deliver the content of the subject. The other challenge was the lack of discussion and participation, resulted from the insufficient level of English proficiency of students. The students would hardly grab the main ideas, information transferred, as they had no understanding of English. These challenges mentioned by Genç in his research in 2017. The last big three challenge was the low level of concentration. This would happen if the students lost in class, with no understanding of the discussion points, so they would not find any interesting part in the learning. 
The factors that lead to successfully implementation of English as a Medium of Instruction were numbers. Here, we would only take the big four which were 1) The adjustment teaching speed considering students' level of English proficiency; 2) the awareness of English as a Medium of Instruction; 3) English proficiency of students; and 4) English proficiency of lecturers.

\section{Conclusion}

To conclude, adopting English as Medium of Instruction (EMI) is essential for sustaining communication in the era of 4.0. Although the implementation of EMI is not always run smoothly due to some drawbacks that could not be avoided by the lecturer, learners and educators need to build awareness to its usage as well as make adjustment in conducting it fully in the classroom. One best thing to do is incorporating the implementation of EMI with the use of technology in the teaching and learning process. As by utilizing technology it would easily be customized with the understanding speed of learners. Online learning would support learners to learn in their own pace as well as decrease the challenges faced by lecturers who teach the class in the era of 4.0 .

For further research, this study recommends the future study to investigate the impact of English as a Medium of Instruction for non-native English students and explore the suitable online learning method which can be used to apply English as a Medium of Instruction effectively.

\section{Acknowledgment}

This research focused on the English as Medium of Instruction Implementation for Communication \& Sustainability in the disruptive era. This research was funded by University of BINA NUSANTARA, known as BINUS University, and as a part of the Applied Research Grant 2019. This research has been proudly presented in ICCoLLiC Conference 2020. Thanks to the committee for the friendly and favorable support.

\section{References}

Angelianawati, L. (2018). Being an English Teacher in Industrial Revolution 4.0: An Overview About Roles, Challenges, and Implications. JDP, 11(3), 307-316. https://doi.org/10.33541/jdp.v11i3.896.

Baena, F., Guarin, A., Mora, J., Sauza, J., \& Retat, S. (2017). Learning Factory: The Path to Industry 4.0. Procedia Manufacturing, 9, 73-80. https://doi.org/10.1016/j.promfg.2017.04.022

Briggs, J. G., Dearden, J., \& Macaro, E. (2018). English medium instruction: Comparing teacher beliefs in secondary and tertiary education. Studies in Second Language Learning and Teaching, 8(3), 673-696. https://doi.org/10.14746/ssllt.2018.8.3.7

Brown, H. (2016). Current Trends in English-medium Instruction at Universities in Japan. Retrieved from https://www.researchgate.net/publication/322212585_Current_Trends_in_Englishmedium_Instruction_at_Universities_in_Japan.

Brown, H., lyobe, B. (2017). The Growth of English Medium Instruction in Japan, Retrieved from https://www.unifg.it/sites/default/files/allegatiparagrafo/06-07 2017/brown_and_iyobe_growth_of_english_medium_instruction_in_japan.pdf. 
Coleman, J. A. (2006). English-medium teaching in European higher education. Language Teaching, 39(1). https://doi.org/10.1017/S026144480600320X.

Corrigan, P. C. (2015). English For the Medium of Instruction (EFMI) at a University in Hong Kong. IAFOR Journal of Education, 3(2). https://doi.org/10.22492/ije.3.2.10

Dafouz, E., \& Camacho-Miñano, M. M. (2016). Exploring the impact of English-medium instruction on university student academic achievement: The case of accounting. English for Specific Purposes, 44, 57-67. https://doi.org/10.1016/j.esp.2016.06.001

Dafouz, E. (2018). English-medium instruction and teacher education programmes in higher education: ideological forces and imagined identities at work. International Journal of Bilingual Education and Bilingualism, 21(5), 540-552. https://doi.org/10.1080/13670050.2018.1487926

Doiz, A., Lasagabaster, D., \& Sierra, J. M. (2011). Internationalisation, multilingualism and English-medium instruction. World Englishes, 30(3), 345-359. https://doi.org/10.1111/j.1467-971X.2011.01718.x

Fitryarini, I. (2018). Participatory Communication and Sustainability Development: Case Study of Coal Mining Environment in East Kalimantan, Indonesia. International Journal of Multicultural and Multireligious Understanding, 5(3), 133. https://doi.org/10.18415/ijmmu.v5i3.275

Genç, R. (2017). The Importance of Communication in Sustainability \& Sustainable Strategies. Procedia Manufacturing, 8, 511-516. https://doi.org/10.1016/j.promfg.2017.02.065

Hariharasudan, A., \& Kot, S. (2018). A Scoping Review on Digital English and Education 4.0 for Industry 4.0. Social Sciences, 7(11), 227. https://doi.org/10.3390/socsci7110227

Kremer, M. M., \& Valcke, M. (2014). Teaching and learning in English in higher education: a literature review. EDULEARN Proceedings (pp. 1430-1441). Presented at the 6th International Conference on Education and New Learning Technologies, IATED. http://hdl.handle.net/1854/LU-5818549

Lalic, B., Majstorovic, V., Marjanovic, U., Delić, M., \& Tasic, N. (2017). The Effect of Industry 4.0 Concepts and E-learning on Manufacturing Firm Performance: Evidence from Transitional Economy. https://doi.org/10.1007/978-3-319-66923-6_35

Macaro, E., Curle, S., Pun, J., An, J., \& Dearden, J. (2018). A systematic review of English medium instruction in higher education. Language Teaching, 51(1), 36-76. https://doi.org/10.1017/S0261444817000350

Nagy, J., Oláh, J., Erdei, E., Máté, D., \& Popp, J. (2018). The Role and Impact of Industry 4.0 and the Internet of Things on the Business Strategy of the Value Chain-The Case of Hungary. Sustainability, 10(10), 3491. https://doi.org/10.3390/su10103491

Piccarozzi, M., Aquilani, B., \& Gatti, C. (2018). Industry 4.0 in Management Studies: A Systematic Literature Review. Sustainability, 10(10), 3821. https://doi.org/10.3390/su10103821

Rojko, A. (2017). Industry 4.0 Concept: Background and Overview. International Journal of Interactive Mobile Technologies (IJIM), 11(5), 77. https://doi.org/10.3991/ijim.v11i5.7072

Santos, B. (2018). Industry 4.0: An Overview. Retrieved from https:// www.researchgate.net/publication/326352993_Industry_40_an_overview

Shahroom, A. A., \& Hussin, N. (2018). Industrial Revolution 4.0 and Education. International Journal of Academic Research in Business and Social Sciences, 8(9). https://doi.org/10.6007/IJARBSS/v8-i9/4593

Shimauchi, S. (2018). English-Medium Instruction in the Internationalization of Higher Education in Japan: Rationales and Issues. Educational Studies in Japan, 12, 77-90. https://doi.org/10.7571/esjkyoiku.12.77 
Shuhaimi, F. L., \& Awaludin, F. A. (2018). English Communication for Digital Technology: Bridging the Gap between Industrial Revolution 4.0 Requirements and Graduates Readiness. Journal of Education and Social Sciences, 10(1). https://www.jesoc.com/wp-content/uploads/2018/08/KC10_12.pdf

Vuksanović, D., Ugarak, J., \& Korčok, D. (2016). Industry 4.0: the Future Concepts and New Visions of Factory of the Future Development. Proceedings of the International Scientific Conference - Sinteza 2016, 293-298. https://doi.org/10.15308/Sinteza-2016293-298

van Ruler, B. (2018). Communication Theory. In The International Encyclopedia of Strategic Communication (pp. 1-7). https://doi.org/10.1002/9781119010722.iesc0087

Zezulka, F., Marcon, P., Bradac, Z., Arm, J., Benesl, T., \& Vesely, I. (2018). Communication Systems for Industry 4.0 and the IloT. IFAC-PapersOnLine, 51(6), 150-155.

https://doi.org/10.1016/j.ifacol.2018.07.145 